\title{
Formulation and characterization of cyclophosphamide injections using lyophilization technique
}

\author{
DMK. Chakradhar ${ }^{1}$, A. Sunitha ${ }^{2}$, B. Sofia ${ }^{3}$, Grandhi Srikar ${ }^{4 *}$ \\ ${ }^{1,4}$ Assistant Professor, ${ }^{2} \mathrm{HOD},{ }^{3}$ Student, ${ }^{2}$ Dept. of Pharmaceutical Analysis, ${ }^{1}$ Raghu College of Pharmacy, Dakamarri, \\ Visakhapatnam, Andhra Pradesh, ${ }^{2}$ Hindu College of Pharmacy, Guntur, Andhra Pradesh, ${ }^{3}$ Emmanuel College of Pharmacy, \\ Visakhapatnam, Andhra Pradesh, ${ }^{4}$ University College of Pharmaceutical Sciences, Acharya Nagarjuna University, Nagarjuna \\ nagar, Guntur, Andhra Pradesh, India
}

\begin{abstract}
Introduction: The parenteral route of administration is generally adopted for rapid onset of action and $100 \%$ bioavailability especially for the drugs which have poor bioavailability through peroral route. Newly developed drugs often show poor solubility and require novel dosage forms such as liposomes, nanoparticles to minimize solubility problems and side effects due to toxicity. These dosage forms are often inherently labile due to agglomeration, sedimentation etc., and can be stabilized and manufactured by freeze drying. Lyophilization is the most common method for manufacturing solid pharmaceuticals products and is central to the preservation of materials which must be dried thoroughly in order to ensure stability and require a gentle, easily sterilizable process.
\end{abstract}

Materials and Methods: The current research work involves the formulation of cyclophosphamide injections using lyophilization technique by using different concentrations of cyclophosphamide. The formulated cyclophosphamide injections are further subjected to different evaluation tests such as melting point, differential scanning calorimetry, dissolution rate study, solution stability, $\mathrm{pH}$ stability, rubber stopper compatibility and photostability.

Results: The moisture content of the formulation is greatly reduced to as low as $0.9 \%(\mathrm{w} / \mathrm{w})$ thus enhancing the stability of the product.

Conclusion: The lyophilized technique proved to be an advantage for the development of stable injectable dosage form of Cyclophosphamide.

Keywords: Lyohilization, Stability, Sterilized, cyclophosphamide, Mannitol.

\section{Introduction}

Parenteral drug administration is generally interpreted as relating to injecting directly into the body, bypassing the skin and mucous membranes. Among all the routes of administration, parenteral administration is the most effective and common form of delivery for active drug substances with poor bioavailability through extravascular routes and the drugs with a narrow therapeutic index. These products are intended for administration by injection through the skin, or other external layers such as stratum corneum and directly into body fluids, tissues, or organs.
The parenteral route of administration is generally adopted for medicaments that cannot be given orally, either because of patient intolerance, instability, therapeutic inactivity, or poor absorption via the enteral route. Injections are often preferred because they can produce an immediate therapeutic response, which can be of prime consideration in clinical conditions such as cardiac arrest, asthma and shock. It produces local effect at the site of action whenever necessary. When food cannot be taken by mouth, the parenteral route can supply total nutritional requirements. The conditions in which prolonged drug action is needed, parenteral forms are available, including the long acting steroids injected intra-

\footnotetext{
*Corresponding Author: Grandhi Srikar, University College of Pharmaceutical Sciences, Acharya Nagarjuna University, Nagarjuna nagar, Guntur, Andhra Pradesh, India 
articularly and the long acting penicillin's administered by deep intra-muscular injection. It helps in correcting serious fluid and electrolyte imbalance within a body. ${ }^{1,2}$

Parenteral are generally liquid formulations, but in case of drugs which require parenteral dosage forms, but poor stable in presence of water, can be developed through Freeze-drying, or lyophilization technique. It is in simple terms a dehydration technique in which an aqueous solution is first frozen and subsequently dried by sublimation under vacuum. The remaining solid undergoes additional drying at elevated temperatures and forms a porous cake with high internal surface area. By reconstituting the lyophilized powder with water for injection, it is easy to achieve a sterile, particle-free and accurately-dosed solution that can be directly administered parenterally. ${ }^{3-7}$ The aspect of freeze-drying process that makes it different from other dehydration techniques is that dehydration takes place while the product is in a frozen state and under a vacuum. These conditions stabilize the product, minimizing the effects of oxidation and other degradation processes. Substances that degrade in solution become candidate of freeze-drying; it has become an accepted method of processing heat sensitive products that require long term storage at temperatures above freezing. ${ }^{8-10}$ Lyophilization has many advantages compared to other drying and preserving techniques such as gentle drying technology for delicate products, properly freeze-dried products can be stored at ambient temperature over a 2 year shelf life, removal of water without excessive heating of the product, enhanced product stability in a dry state. ${ }^{11-13}$

Cyclophosphamide is biotransformed principally in the liver to active alkylating metabolites by a mixed function microsomal oxidase system. These metabolites interfere with the growth of susceptible rapidly proliferating malignant cells. The mechanism of action is thought to involve cross linking of tumor cell DNA. The current research work involves the formulation of cyclophosphamide injections using lyophilization technique.

\section{Materials and Methods}

Cyclophosphamide monohydrate was purchased from Shilpa medicare Ltd, Hyderabad. Mannitol was purchased from Roquette Pvt Ltd, Karnataka. All the chemicals used in this research were of analytical grade.

\section{Melting point}

Melting point was determined using melting point apparatus. The sample was placed in apparatus and observed for the temperature at which the drug melts.

\section{Differential scanning calorimetry}

The heat characteristics of sample were analyzed using a differential scanning calorimetric (DSC 60 shimadzu). Behaviour under heat was studied by heating the sample $(2 \mathrm{mg})$ in an aluminium pan from $25^{\circ} \mathrm{C}$ to $350^{\circ} \mathrm{C}$, a rate of heating of $10^{\circ} \mathrm{C} \cdot \mathrm{min}^{-1}$, under a flow of nitrogen of $10 \mathrm{~cm}^{3} \mathrm{~min}^{-1}$, using an empty pan as a point of reference.

\section{Dissolution rate study}

The dissolution of each and every ingredient used in the formulation was checked and the time, temperature and stirring speed were recorded to assess the solubility status of cyclophosphamide and mannitol.

\section{Formulation of cyclophosphamide injections}

$80 \%$ of required batch quantity of milli-Q water was collected in a clean dry duran bottle. To that milli-Q water, the calculated and dispensed quantity of API was added and stirred until it was dissolved completely. To the above solution, mannitol was added and kept for stirring until it was completely dissolved. The above solution was then made to $100 \%$ of its batch size with the remaining quantity of milli-Q water collected. After final volume was made, the solution was then allowed to stir for about 5 minutes in order to get a clear homogenous solution. The above homogenous bulk solution was then filtered through $0.2 \mu$ membrane filter with the help of vacuum pump and finally filled into dry duran bottle. After filling, the filled vials were loaded into lyophilizer and subjected to lyophilization process to get the finished lyophilized product. Three different concentrations of cyclophosphamide was used for the formulation of 
different cyclophosphamide injections as mentioned in Table 1.

\section{Solution stability}

Solution stability is a necessary tool to determine stability of drug in solution form and also helpful in estimating the time to process lyophilization.

\section{pH stability}

The $\mathrm{pH}$ stability is carried out to determine its stability of drug in solution form upon long term storage.

\section{Rubber closure compatibility}

Rubber closure compatibility studies were conducted by using uncoated, Teflon coated and Grey bromobutyl double slotted rubber stopper. Drug solution prepared was closed and kept in inverted position in stability chamber for a week. Samples were collected at regular time intervals and assay was performed to know the loss in drug content. Grey bromobutyl double slotted rubber stopper are used as it showed less variation in drug content.

\section{Physical appearance of the product}

The physical appearance of the final product was checked to determine the nature of the product developed.

\section{Evaluation of lyophilized product}

The developed Lyophilized product was reconstituted with $0.9 \%$ Sodium Chloride and then it was evaluated for different test parameters like completeness, clarity, particulate matter, reconstitution time, $\mathrm{pH}$ after reconstitution, water content and assay.

\section{Photo stability study}

The photostability study was carried to verify if the spectra of the developed product was concordant with the reference spectra thereby indicating its stability when exposed to light.

\section{Results and Discussion \\ Melting point}

The melting point of the drug was determined to be within a range of $49.5-53^{\circ} \mathrm{C}$.

Table 1: Formulation code of different concentrations of cyclophosphamide injections

\begin{tabular}{|c|c|c|c|c|c|}
\hline \multirow[t]{2}{*}{ S. No } & \multirow[t]{2}{*}{ Ingredient } & \multirow{2}{*}{$\begin{array}{l}\text { Quantity } \\
\text { (mg/mL) }\end{array}$} & \multicolumn{3}{|c|}{ mg/unit } \\
\hline & & & $\begin{array}{c}500 \\
\text { mg/vial }\end{array}$ & $1 \mathrm{~g} /$ vial & $2 \mathrm{~g} / \mathrm{vial}$ \\
\hline 1 & $\begin{array}{l}\text { Cyclophosphamide } \\
\text { monohydrate }\end{array}$ & $30 \mathrm{mg}$ & $500 \mathrm{mg}$ & $1000 \mathrm{mg}$ & $2000 \mathrm{mg}$ \\
\hline 2 & Mannitol & $22.5 \mathrm{mg}$ & $375 \mathrm{mg}$ & $750 \mathrm{mg}$ & $1500 \mathrm{mg}$ \\
\hline 3 & Milli Q water & qs & qs & qs & qs \\
\hline
\end{tabular}

qs*- quantity sufficient

\section{Differential scanning calorimetry}

Figure 1 represents the total heat flow as a function of temperature. The upper line in the thermogram denotes the cooling run from equilibrium temperature $25^{\circ} \mathrm{C}$ to $-40^{\circ} \mathrm{C}$. During this run at exothermic recrystallization peak contributed by the ice formation was seen at a temperature of around $-7.69^{\circ} \mathrm{C}$.

The lower line in the thermo gram denotes the heating run from-10c to $-6^{0} \mathrm{C}$, it could be seen that at a temperature of $-7.42^{0} \mathrm{C}$, eutectic melt was observed. The phase change temperature during DSC freezing point for the formulation is $-7.69^{\circ} \mathrm{C}$ and during was identified as $-7.42^{\circ} \mathrm{C}$ considering freezing point and eutectic melt temperature the initial set temperature during freezing was selected as $5^{0} \mathrm{C}$ with a hold of 60 minutes to achieve the uniform temperature across the vials and avoid vial to vial temperature variation. The final freezing temperature was proposed as $-40^{\circ} \mathrm{C}$ to ensure the complete freezing of the drug product. During the primary drying a cautious approach was selected as the initial shelf temperature was proposed as $-5^{0} \mathrm{C}$ for the primary drying. 


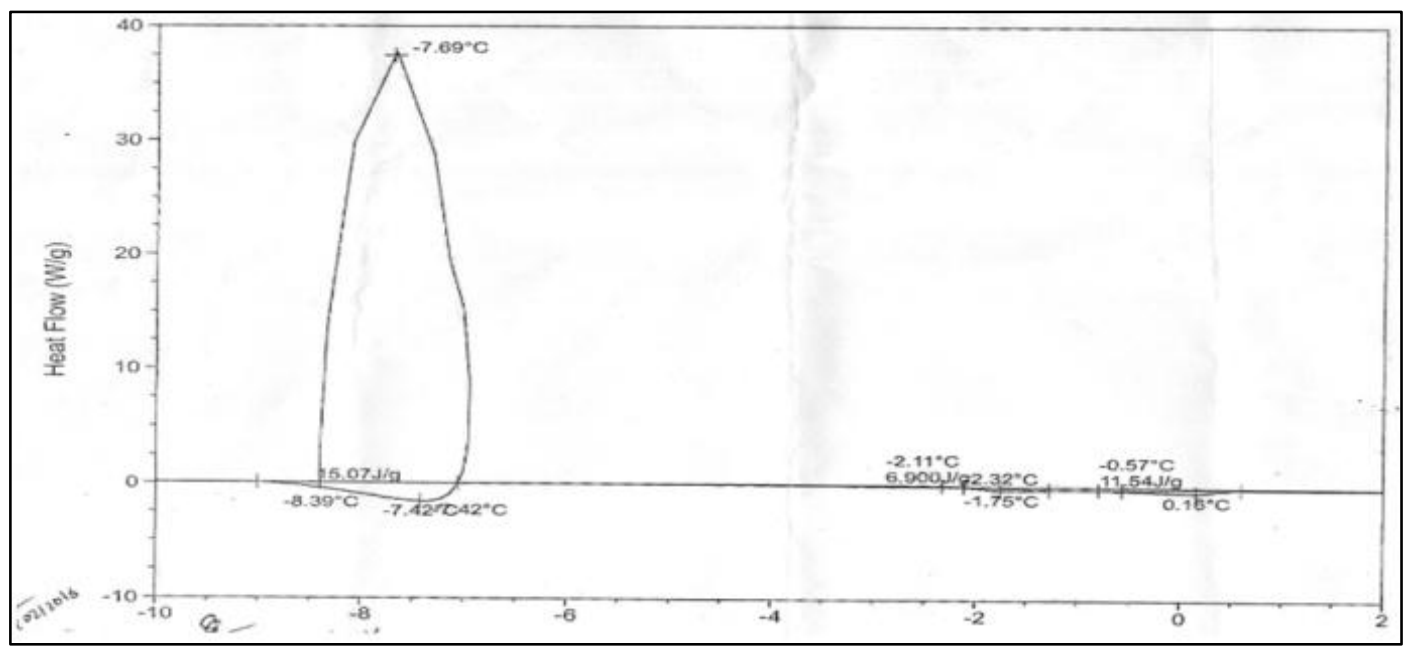

Fig 1: DSC of cyclophosphamide

\section{Dissolution rate study}

The dissolution rate study at different temperatures and rpm was carried and the results were as shown in table 2 .

Table 2: Dissolution data

\begin{tabular}{|c|c|c|c|c|}
\hline Ingredient & Temperature & Motor speed RPM & Time & Solubility status \\
\hline $\begin{array}{c}\text { Cyclophosphamide } \\
\text { monohydrate }\end{array}$ & $2-8^{\circ} \mathrm{C}$ & 550 & $140 \mathrm{~min}$ & Soluble \\
\cline { 2 - 5 } & $25^{\circ} \mathrm{C}$ & 550 & $30 \mathrm{~min}$ & Soluble \\
\cline { 2 - 5 } & $15^{\circ} \mathrm{C}$ & 550 & $50 \mathrm{~min}$ & Soluble \\
\hline \multirow{3}{*}{ Mannitol } & $2-8^{\circ} \mathrm{C}$ & 550 & $10 \mathrm{~min}$ & Soluble \\
\cline { 2 - 5 } & $25^{\circ} \mathrm{C}$ & 550 & $4 \mathrm{~min}$ & Soluble \\
\cline { 2 - 5 } & $15^{\circ} \mathrm{C}$ & 550 & $6 \mathrm{~min}$ & Soluble \\
\hline
\end{tabular}

\section{Solution stability}

The results of the solution stability are mentioned in table 3 from which it can be inferred that initially the drug content was $100.2 \%$ and the drug content dropped to 92.6 after 48 hours and a change in the colour was also observed due to drug degradation. Hence it can be concluded that cyclophosphamide in solution form should be used within $24 \mathrm{hrs}$. either for medication or for lyophilization.

Table 3: Solution stability

\begin{tabular}{|c|c|c|c|}
\hline S. No. & Time Period & Drug Content (\%) & Appearance \\
\hline 1. & Initial & 101.2 & Off white solution \\
\hline 2. & After 24 hrs. & 97.8 & Off white solution \\
\hline 3. & After 48 hrs. & 92.6 & Pale yellow color \\
\hline
\end{tabular}

\section{pH stability}

Drug solution was taken at different $\mathrm{pH}$ and studied for 2 weeks at elevated temperatures. Samples were collected at intermediate stages and assay was performed. From the table 4 it was found that $\mathrm{pH} 6.8$ was stable. 
Table 4: pH Stability

\begin{tabular}{|c|c|c|c|}
\hline \multirow{2}{*}{ S. No. } & \multirow{2}{*}{ pH } & \multicolumn{2}{|c|}{ Assay in \% } \\
\cline { 3 - 4 } & & First week & Second week \\
\hline 1. & 4.3 & 100.9 & 99.7 \\
\hline 2. & 6.8 & 101.2 & 101.0 \\
\hline 3. & 7.5 & 98.7 & 97.85 \\
\hline
\end{tabular}

\section{Rubber closure compatibility}

It was inferred from the results shown in table 5 that the grey bromobutyl double slotted rubber stopper was found to be more compatible to the final product.

Table 5: Rubber closure compatibility

\begin{tabular}{|c|c|c|c|c|}
\hline \multirow{2}{*}{ S. No. } & Type of rubber stopper & \multicolumn{3}{|c|}{ Drug Content (\%) } \\
\cline { 3 - 5 } & Grey bromobutyl double slotted rubber \\
stopper & 100.2 & 100.2 & 100.0 \\
\hline 1. & Teflon coated & 100.0 & 99.7 & 99.5 \\
\hline 2. & Uncoated & 100.8 & 99.8 & 99.4 \\
\hline 3. & \multicolumn{2}{|c|}{ day } & $\mathbf{6}^{\text {th }}$ day \\
\hline
\end{tabular}

\section{Physical appearance of the product}

From the table 6, the nature of the product for each trial conducted was observed and it was further concluded that the Trial 7 was optimum and the product was excellent based on the tests performed to the lyophilized product.

Table 6: Physical appearance of drug product

\begin{tabular}{|c|c|c|}
\hline S. No. & Trials & Nature of the product \\
\hline 1. & Trial 1 & Cake was not formed properly \\
\hline 2. & Trial 2 & Cake formed but sticky \\
\hline 3. & Trial 3 & Damp cake \\
\hline 4. & Trial 4 & Damp cake \\
\hline 5. & Trial 5 & Damp cake \\
\hline 6. & Trial 6 & White lyophilized cake, but final moisture content was high \\
\hline 7. & Trial 7 & White lyophilized cake, but final moisture content was within the limit \\
\hline
\end{tabular}

\section{Evaluation of lyophilized product}

The results of the evaluation of the lyophilized product conclude that the recipe set for the lyophilizaton process resulted in a good cake of the drug product with low water content and all the remaining test parameters were found to be in the specified limits as shown in Table 7.

Table 7: Evaluation of Lyophilized product

\begin{tabular}{|c|c|c|c|}
\hline S. No. & \multicolumn{1}{|c|}{ Test parameter } & Specifications & Observations \\
\hline 1. & Description & $\begin{array}{c}\text { White to off white lyophilized } \\
\text { cake/powder }\end{array}$ & White lyophilized cake \\
\hline 2. & $\begin{array}{l}\text { Constituted solution } \\
\text { a) Completeness and clarity } \\
\text { of solution }\end{array}$ & $\begin{array}{c}\text { The solid should dissolve completely } \\
\text { leaving no visible undissolved residue }\end{array}$ & $\begin{array}{c}\text { Cake dissolved } \\
\text { completely and it is } \\
\text { clear }\end{array}$ \\
\hline
\end{tabular}




\begin{tabular}{|c|c|c|c|}
\hline & b) Particulate matter & $\begin{array}{c}\text { The solution is essentially free from } \\
\text { foreign matter that can be observed on } \\
\text { visual inspection }\end{array}$ & $\begin{array}{c}\text { Free from visible } \\
\text { particles }\end{array}$ \\
\hline 3. & Reconstitution time & Not more than $120 \mathrm{~s}$ & $50 \mathrm{~s}$ \\
\hline 4. & $\mathrm{pH}$ after reconstitution & Between 4.0 to 9.0 & 6.67 \\
\hline 5. & Water content & To be established & $6.0 \%$ \\
\hline 6. & Assay & NLT 95\% and NMT $110 \%$ & 100.2 \\
\hline
\end{tabular}

Table 8: Photostability study

\begin{tabular}{|c|c|c|c|c|c|c|}
\hline S. No. & Test parameter & Initial & $\begin{array}{c}\text { Control } \\
\text { (Aluminium } \\
\text { wrapped) }\end{array}$ & $\begin{array}{c}\text { Secondary } \\
\text { pack }\end{array}$ & $\begin{array}{c}\text { Primary pack } \\
\text { (delabelled) }\end{array}$ & $\begin{array}{c}\text { Primary pack } \\
\text { (labelled) }\end{array}$ \\
\hline 1. & Description & $\begin{array}{c}\text { White } \\
\text { lyophilized } \\
\text { cake/powder }\end{array}$ & $\begin{array}{c}\text { White } \\
\text { lyophilized } \\
\text { cake/powder }\end{array}$ & $\begin{array}{c}\text { White } \\
\text { lyophilized } \\
\text { cake/powder }\end{array}$ & $\begin{array}{c}\text { White } \\
\text { lyophilized } \\
\text { cake/powder }\end{array}$ & $\begin{array}{c}\text { White } \\
\text { lyophilized } \\
\text { cake/powder }\end{array}$ \\
\hline 2 & Assay & 101.2 & 100.1 & 99.8 & 98.6 & 97.3 \\
\hline 3. & $\begin{array}{c}\text { pH after } \\
\text { reconstitution }\end{array}$ & 4.3 & 4.32 & 4.44 & 4.53 & 4.67 \\
\hline 4. & $\begin{array}{c}\text { Identification by } \\
\text { IR }\end{array}$ & $\begin{array}{c}\text { Concordant } \\
\text { with } \\
\text { reference } \\
\text { spectra }\end{array}$ & $\begin{array}{c}\text { Concordant } \\
\text { with } \\
\text { reference } \\
\text { spectra }\end{array}$ & $\begin{array}{c}\text { Concordant } \\
\text { with } \\
\text { reference } \\
\text { spectra }\end{array}$ & $\begin{array}{c}\text { Concordant } \\
\text { with } \\
\text { reference } \\
\text { spectra }\end{array}$ & $\begin{array}{c}\text { Concordant } \\
\text { with } \\
\text { reference } \\
\text { spectra }\end{array}$ \\
\hline 5. & Water content & 6.0 & 6.09 & 6.19 & 6.2 & 6.13 \\
\hline 6. & $\begin{array}{c}\text { Reconstitution } \\
\text { time }\end{array}$ & $35 \mathrm{~s}$ & $45 \mathrm{~s}$ & $40 \mathrm{~s}$ & $50 \mathrm{~s}$ & $43 \mathrm{~s}$ \\
\hline 7. & $\begin{array}{c}\text { Constituted } \\
\text { solution }\end{array}$ & $\begin{array}{c}\text { Clear, } \\
\text { colorless } \\
\text { solution }\end{array}$ & $\begin{array}{c}\text { Clear, } \\
\text { colorless } \\
\text { solution }\end{array}$ & $\begin{array}{c}\text { Clear, } \\
\text { colorless } \\
\text { solution }\end{array}$ & $\begin{array}{c}\text { Light pale } \\
\text { yellow color }\end{array}$ & $\begin{array}{c}\text { Light pale } \\
\text { yellow color }\end{array}$ \\
\hline
\end{tabular}

\section{Photostability study}

It can be inferred from the results of the photo stability study that the drug content of the final product wrapped in aluminium (control) remained almost constant when compared to the other packagings. The $\mathrm{pH}$ and the water content of the aluminium wrapped product (control) was similar as the initial product.

\section{Conclusion}

The lyophilized technique proved to be an advantage for the development of stable injectable dosage form of Cyclophosphamide as the moisture content of the formulation is greatly reduced to as low as $0.9 \%(\mathrm{w} / \mathrm{w})$ thus enhancing the stability of the product, ease of handling, rapid dissolution because of porous nature of the cake and easier transport of the material during shipping. Based on the stability studies it was concluded that the Cyclophosphamide for injection is stable at room temperature. It was inferred from the photo stability studies that Cyclophosphamide was not photo sensitive drug and hence there is no requisite for the protection from light.

\section{Source of Funding}

None.

\section{Conflicts of Interest}

None. 


\section{References}

1. Indian Pharmacopoeia volume 1 1996, Published by controller of publications.

2. Malenka, Eric J Nestler, Steven E. Hyman, Robert C. Molecular Neuropharmacology: A Foundation for Clinical Neuroscience. $3^{\text {rd }}$ edition. McGraw-Hill Medical, Newyork, 2009.

3. Jennings TA. "Lyophilization: Introduction and Basic Principles". Englewood. Co: Interpharm Press. 1999

4. Constantino HR, Pikal MJ, American Association of Pharmaceutical Scientists. 2004

5. Cameron P. Good pharmaceutical Freeze Drying Practice. Interpharm Press. 1997

6. Pikal MJ, Roy ML, Shah S. Mass and heat transfer in vial freeze-drying of pharmaceuticals: role of the vial. J Pharm Sci 1984;73(9):1224-37.

7. Brulls M, Rasmuson A. Heat transfer in vial lyophilization. Int J Pharm 2002;246(1-2):1-16.

8. Kuu W Y, Hardwick L M, Akers M J. Correlation of laboratory and production freeze drying cycles. Int J Pharm 2005; 302(1-2):56-67.
9. Kuu W Y, Nail S L, Sacha G. Rapid determination of vial heat transfer parameters using tunable diode laser absorption spectroscopy (TDLAS) in response to stepchanges in pressure set-point during freeze-drying. J Pharm Sci 2009;98(3):1136-54.

10. Pikal M J. Heat and Mass Transfer in Low Pressure Gases: Applications to Freeze Drying, 2002, 610-80.

11. Nail S L, Jiang S, Chongprasert S, Knopp S A. Fundamentals of freeze-drying. Pharm Biotechnol 2002;14:281-360.

12. Baheti A, Kumar L, Bansal AK: Excipients used in Lyophilization of small molecules, J Excipients Food Chem 2010; 1(1):41-54.

13. Tang X, Pikal MJ. Design of freeze-drying processes for pharmaceuticals: practical advice. Pharm Res 2004;21(2):191-200.

How to cite this article: Chakradhar DMK, Sunitha A, Sofia B, Srikar G. Formulation and characterization of cyclophosphamide injections using lyophilization technique. Int J Pharm Chem Anal 2019;6(3):69-75 